\title{
Penyapihan Dini, Toilet Training dan Pola Asuh serta Pengaruhnya pada Temper Tantrum
}

\author{
Eny Qurniyawati ${ }^{1}$, Riska Ratnawati ${ }^{2}$ \\ ${ }^{1}$ Fakultas Kesehatan Masyarakat Universitas Airlangga \\ ${ }^{2}$ Fakultas Kesehatan Masyarakat Stikes Bhakti Husada Mulia
}

\section{ABSTRACT}

Background: Child development includes physical, psychological and social aspects. The imbalance stimulation provided by parents could develop temper tantrum of child as a form of emotional explosion. The influence factors of tantrum among children are early weaning, improper toilet training, and the way of parenting in tantrum. This study aims to examine factors influence on temper tantrum among pre-school children.

Method: This is descriptive analytical study with case control design. The number of case sample which selected from mothers who have tantrum pre-school child was 42 mothers and 42 control sample were also selected from mothers who have no tantrum child. Data were analyzed by univariate, bivariate (Chi-Square) and multivariate using logistic regression to examine the most influenced factors.

Results: The study shows that early weaning, toilet training and parenting method were significantly influence on temper tantrum of pre-school children. The most influential variable was the parenting method with OR 9,09 and p-value 0,021. It means negative parenting method 9 times higher influence on tantrum temper behavior among children compared to positive parenting method. It is suggested that parenting method should emphasize more in educative and discipline including responsibility aspects.

Correspondence

enyqur88@gmail.com

\section{Article History}

Received 19 June 2019

Revised 19 July 2019

Accepted 4 December 2019

Available Online 6 March 2020

Keywords

Early warning

Toilet training

Parenting

Temper tantrum

DOI

10.14710/jpki.15.1.31-35

\section{PENDAHULUAN}

Tahapan kehidupan seorang anak dalam masa tumbuh kembang salah satunya adalah masa toddler. Masa toddler merupakan masa kanak-kanak mulai belajar berjalan sampai berjalan sendiri dan berlari dengan mudah, yaitu antara usia 12 sampai 36 bulan. ${ }^{1}$

Di Indonesia diperkirakan jumlah toddler mencapai 40\% dari 295 juta jiwa penduduk Indonesia di tahun 2015. Menurut Survei Kesehatan Rumah Tangga (SKRT) tahun 2014, diperkirakan jumlah balita yang masih sulit mengontrol BAB dan BAK (mengompol) sampai usia prasekolah mencapai 75 juta anak. Kejadian anak mengompol lebih besar jumlah persentase anak laki-laki yaitu $60 \%$ dan anak perempuan $40 \% .^{2}$ Berdasarkan penelitian American Academy of Pediatrics (AAP) menyatakan bahwa tidak semua anak siap untuk melakukan toilet training pada usia 2 tahun. Hasil penelitian ini menunjukan bahwa hanya $4 \%$ dari 482 toddler yang sehat mampu untuk toilet training pada usia 2 tahun, 22\% pada usia 2,5 tahun, $60 \%$ pada usia 3 tahun, $88 \%$ pada usia 3,5 tahun dan $2 \%$ pada usia 4 tahun. Pola asuh merupakan suatu sistem atau cara pendidikan dan pembinaan yang diberikan oleh orang tua kepada anaknya. Jadi, pengasuhan anak adalah kepemimpinan dan bimbingan kepada anak yang berkaitan dengan kepentingan hidup, perkembangan, seperti masalah perkembangan emosi yang biasanya terjadi pada anak, dengan salah satu gangguan diantaranya yaitu temper tantrum. ${ }^{3}$ Temper tantrum dapat diartikan sebagai ledakan emosi atau luapan kemarahan yang dilakukan anak kecil. Tingkah laku ini biasanya mencapai titik terburuk sekitar usia 18 bulan hingga 3 tahun, dan kadang masih ditemui pada anak usia 5 atau 6 tahun. ${ }^{4}$ Kesalahan yang sering dilakukan oleh orang tua yaitu menerapkan pola asuh yang salah. Anak terlalu dimanjakan dan selalu mendapatkan apa yang diinginkan, bisa temper tantrum ketika permintaannya ditolak. Anak yang terlalu dilindungi dan didominasi oleh orang tuanya, suatu ketika bisa bereaksi menentang dominasi orang tua dengan perilaku tantrum. Temper tantrum yang tidak ditangani sejak dini, maka tantrum yang buruk pada usia 3 tahun akan terbawa sebagai masalah sampai masa dewasa. Sebuah fakta penelitian mengungkapkan bahwa anak yang pemarah (temper tantrum) sering tumbuh menjadi orang dewasa yang pemarah (temper tantrum) pula. 5,6 


\section{METODE}

Penelitian ini menganalisis pengaruh penyapihan dini, toilet training, dan pola asuh terhadap perilaku temper tantrum anak pra sekolah di Desa Genengan, Kecamatan Kawedanan, Kabupaten Magetan. Rancangan yang digunakan adalah case control. Variabel independen pada penelitian adalah penyapihan dini, toilet training dan pola asuh. Sedangkan variabel terikat adalah perilaku temper tantrum. Sampel sebanyak 42 responden dengan purposive sampling yaitu orang tua atau wali murid dari anak Pra sekolah yang berada di TK Desa Genengan, Kecamatan Kawedanan, Kabupaten Magetan. Pengumpulan data menggunakan kuesioner dengan skala sikap. Analisis bivariat yang dengan uji statistik Chi-Square $\left(\mathrm{x}^{2}\right)$ pada SPSS (statistic product service solution) 16.0 forWindows. Analisis multivariat menggunakan multiple regression logistic.

\section{HASIL DAN PEMBAHASAN}

Temper tantrum adalah perilaku destruktif dalam bentuk luapan yang bisa bersifat fisik (memukul, menggigit, mendorong), maupun verbal (menangis, berteriak, merengek) atau terus menerus merajuk. Faktor penyebab anak mengalami temper tantrum antara lain faktor fisiologis, yaitu lelah, lapar atau sakit; faktor psikologis, antara lain anak mengalami kegagalan, dan orang tua yang terlalu menuntut anak sesuai harapan orangtua; faktor orang tua, yakni pola asuh; faktor lingkungan, yaitu lingkungan keluarga dan lingkungan luar rumah. Hasil analisis deskriptif yang mencerminkan karakteristik sosiodemografi responden memperlihatkan anak yang berperilaku temper tantrum hampir seluruhnya pada ibu dengan usia risiko rendah yaitu 20-35 tahun. Hal ini berbeda dengan hasil penelitian Qurniyawati tahun 2017 sebanyak 56,2\% yaitu ibu dengan usia $>35$ tahun yang menyatakan bahwa pada seorang ibu yang berusia dewasa dimungkinkan akan lebih sulit dilakukan modifikasi persepsi dan tingkah laku dibandingkan dengan seseorang yang berusia lebih muda. ${ }^{7}$ Usia 20-35 tahun merupakan kategori usia dewasa awal, dimana perkembangan psikososialnya sebagai seorang individu yang mulai membina rumah tangga dan menjadi orang tua.

Hampir seluruhnya perilaku temper tantrum pada ibu dengan berpendidikan tinggi. Hal ini sejalan dengan pendapat Baker dan Lopez tahun 2010 yang menjelaskan bahwa pengetahuan yang didapatkan dengan pendidikan maka akan semakin paham dengan materi serta strategi dalam menerapkan stimulasi yang baik.

Hasil penelitian bahwa temper tantrum sebagian besar pada ibu bekerja sejalan dengan Achmad et all tahun 2015 yang menyatakan bahwa pada status ibu mempunyai peranan penting dalam mengasuh anaknya, ibu yang tidak bekerja harus mempunyai waktu yang cukup untuk memberikan stimulus kepada anaknya. Ibu yang tidak bekerja dan bekerja juga dapat berpengaruh pada tumbuh kembang anaknya. Ibu yang bekerja dapat menghabiskan sebagian waktunya pada pekerjaannya sedangkan ibu yang tidak bekerja dapat memperhatikan anaknya setiap saat. ${ }^{8}$

Tabel 1. Distribusi frekuensi berdasarkan latar belakang karakteristik ibu siswa di TK Desa Genengan

\begin{tabular}{|c|c|c|c|c|c|c|}
\hline \multirow{3}{*}{ Karakteristik } & \multicolumn{4}{|c|}{ Temper Tantrum } & \multirow{2}{*}{\multicolumn{2}{|c|}{ Jumlah }} \\
\hline & \multicolumn{2}{|c|}{ Sikap Positif } & \multicolumn{2}{|c|}{ Sikap Negatif } & & \\
\hline & $\mathrm{n}$ & $\%$ & $\mathrm{n}$ & $\%$ & $\mathrm{n}$ & $\%$ \\
\hline \multicolumn{7}{|l|}{ Umur } \\
\hline Risiko Tinggi ( $>35$ tahun) & 7 & 29,2 & 2 & 11,1 & 9 & 21,4 \\
\hline Risiko Rendah (20-35 tahun) & 17 & 70,8 & 16 & 88,9 & 33 & 78,6 \\
\hline \multicolumn{7}{|l|}{ Tingkat Pendidikan } \\
\hline Tinggi ( $\geq$ tamat SMP) & 21 & 87,5 & 18 & 100 & 39 & 92,9 \\
\hline Rendah (<tamat SMP) & 3 & 12,5 & 0 & 0 & 3 & 7,1 \\
\hline \multicolumn{7}{|l|}{ Pekerjaan } \\
\hline Bekerja & 19 & 79,2 & 15 & 83,3 & 34 & 81,0 \\
\hline Tidak bekerja & 5 & 20,8 & 3 & 16,7 & 8 & 19,0 \\
\hline \multicolumn{7}{|l|}{ Usia Anak } \\
\hline Balita & 15 & 62,5 & 5 & 27,8 & 20 & 47,6 \\
\hline Pra sekolah & 9 & 37,5 & 13 & 72,2 & 22 & 52,4 \\
\hline \multicolumn{7}{|l|}{ Jenis Kelamin } \\
\hline Perempuan & 14 & 58,3 & 7 & 38,9 & 21 & 50,0 \\
\hline Laki-laki & 10 & 41,7 & 11 & 61,1 & 21 & 50,0 \\
\hline
\end{tabular}


Tabel 2. Hasil crosstab antara penyapihan dini, toilet training dan pola asuh terhadap perilaku temper tantrum

\begin{tabular}{|c|c|c|c|c|c|c|c|c|c|c|}
\hline \multirow{3}{*}{ Variabel } & \multicolumn{4}{|c|}{ Temper tantrum } & \multirow{2}{*}{\multicolumn{2}{|c|}{ Total }} & \multirow{3}{*}{$\begin{array}{c}p \\
\text { value }\end{array}$} & \multirow{3}{*}{ OR } & \multirow{2}{*}{\multicolumn{2}{|c|}{$95 \% \mathrm{CI}$}} \\
\hline & \multicolumn{2}{|c|}{ Sikap positif } & \multicolumn{2}{|c|}{ Sikap negatif } & & & & & & \\
\hline & $\mathrm{n}$ & $\%$ & $\mathrm{n}$ & $\%$ & $\mathrm{n}$ & $\%$ & & & Lower & Upper \\
\hline \multicolumn{11}{|l|}{ Penyapihan Dini } \\
\hline Tidak Penyapihan dini & 19 & 79,2 & 6 & 33,3 & 25 & 59,5 & 0,003 & 7,60 & 1,89 & 30,50 \\
\hline Penyapihan Dini & 5 & 20,8 & 12 & 66,7 & 17 & 40,5 & & & & \\
\hline \multicolumn{11}{|l|}{ Toilet Training } \\
\hline Sikap Positif & 17 & 70,8 & 7 & 38,9 & 24 & 57,1 & 0,038 & 3,82 & 1,05 & 13,91 \\
\hline Sikap Negatif & 7 & 29,2 & 11 & 61,1 & 18 & 42,9 & & & & \\
\hline \multicolumn{11}{|l|}{ Pola Asuh } \\
\hline Sikap Positif & 17 & 70,8 & 7 & 38,9 & 24 & 57,1 & 0,038 & 3,82 & 1,05 & 13,91 \\
\hline Sikap Negatif & 7 & 29,2 & 11 & 61,1 & 18 & 42,9 & & & & \\
\hline
\end{tabular}

Tabel 3. Hasil analisis regresi logistik ganda penyapihan dini, toilet training, pola asuh dan pengaruhnya pada perilaku temper tantrum

\begin{tabular}{|c|c|c|c|c|c|}
\hline \multirow{2}{*}{ Variabel } & \multirow{2}{*}{$\beta$} & \multirow{2}{*}{ Sig. } & \multirow{2}{*}{ OR } & \multicolumn{2}{|c|}{$95 \% \mathrm{CI}$} \\
\hline & & & & Lower & Upper \\
\hline Penyapihan Dini & 2,093 & 0,013 & 8,11 & 1,56 & 42,19 \\
\hline Toilet Training & 2,116 & 0,023 & 8,29 & 1,34 & 51,47 \\
\hline Pola Asuh & 2,207 & 0,021 & 9,09 & 1,40 & 58,88 \\
\hline
\end{tabular}

Ket:

$\mathrm{N}$ observasi $=42$

-2 Log Likelihood $=37,336$

Nagelkerke $\mathrm{R}^{2}=50,9 \%$

Pada penelitian ini pada anak laki-laki lebih cenderung mengalami temper tantrum. Hal ini sejalan dengan penelitian Lestari tahun 2013 yang menyatakan bahwa kejadian anak mengompol lebih besar jumlah persentase anak laki-laki yaitu $60 \%$ dan anak perempuan $40 \%$, artinya anak laki-laki memiliki kontrol emosi yang lebih rendah daripada anak perempuan. ${ }^{2}$

Berdasarkan tabel 2, persentase (\%) sikap temper tantrum lebih dari setengahnya pada orang tua yang melakukan penyapihan dini $(66,7 \%)$ dibandingkan yang tidak melakukan penyapihan dini sebesar 33,3\%. Kepercayaan penyapihan dini dalam mempengaruhi perilaku temper tantrum sebesar 7,60 kali (95\% CI=1,89-30,50). Menyapih adalah proses berhentinya masa menyusui secara berangsur-angsur atau sekaligus dan merupakan masa yang paling kritis dalam kehidupan anak. ${ }^{9}$

Risiko tidak memberikan ASI eksklusif untuk bayi adalah terganggunya pertumbuhan dan perkembangan saraf. ${ }^{10}$ Pernyataan ini diperkuat oleh Nugroho tahun 2012 bahwa lamanya pemberian ASI berpengaruh positif terhadap perkembangan personal sosial, yaitu penyesuaian diri di masyarakat dan kebutuhan pribadi. ${ }^{11}$ Dengan baiknya perkembangan pada aspek sosial, maka akan mengurangi kejadian perilaku temper tantrum pada anak. Ibu yang mempunyai pengetahuan baik tentang manfaat ASI selama dua tahun bagi sang anak, dimungkinkan akan mempengaruhi waktu penyapihan pada anaknya. ${ }^{12}$ Ibu dalam memberikan ASI selain untuk memenuhi kebutuhan gizi anak bisa sebagai bentuk kasih sayang ibu terhadap anaknya. Dengan penyapihan dini, maka akan berkurang bounding ibu dengan anak, sehingga anak merasa tidak nyaman, dan berdampak pada perilaku negatif yang mengarah pada perilaku temper tantrum. Jadi semakin lama dalam menyusui anak, maka semakin bagus pula perkembangan anaknya.

Peranan toilet training dan pola asuh menunjukkan hubungan secara statistik dan signifikan dalam pengaruhnya pada perilaku temper tantrum. Hal ini dibuktikan pada persentase (\%) perilaku temper tantrum lebih dari setengahnya $(61,1 \%)$ pada orang tua yang memberikan sikap positif pada toilet training dan pola asuh dibandingkan orang tua yang bersikap negatif pada toilet training dan bersikap negatif dalam pemberian pola asuh $(38,9 \%)$. Peranan toilet training dalam memberikan pengaruh pada perilaku temper tantrum sebesar 3,82 kali $(95 \% \mathrm{CI}=1,05-13,91)$ angka ini sama nilainya dengan peranan peranan pola asuh terhadap perilaku temper tantrum.

Hasil penelitian membuktikan bahwa toilet training mempengaruhi terjadinya perilaku temper tantrum. Konsep toilet training memang belum banyak dipahami dikalangan masyarakat, hal ini disebabkan karena informasi terkait tentang toilet training tidak dikenalkan secara umum di masyarakat, sedangkan fenomena yang terjadi di masyarakat akibat dari konsep toilet training yang tidak diajarkan secara benar atau kurang tepat sangatlah tidak sedikit hal ini karena dampak negative yang ditimbulkan tidaklah dapat dilihat secara langsung, ini yang menyebabkan konsep toilet 
training dipandang tidaklah penting dalam tahap perkembangan anak usia toddler. Hockenbery, Wilson, \& Wong tahun 2012 menguatkan bahwa toilet training merupakan salah satu tugas dari perkembangan anak pada usia toddler. ${ }^{13}$

Dampak paling umum yang terjadi dalam kegagalan toilet training diantaranya adalah adanya perlakuan atau aturan yang ketat dari orangtua kepada anaknya, sehingga dapat mengganggu kepribadian anak dan cenderung bersikap keras kepala bahkan kikir, seperti orangtua sering memarahi anak pada saat $\mathrm{BAB}$ atau $\mathrm{BAK}$ atau bahkan melarang $\mathrm{BAB}$ atau BAK saat bepergian. Selain itu, apabila orangtua juga santai dalam memberikan aturan dalam toilet training, maka anak dapat mengalami kepribadian ekspresif, seperti anak menjadi lebih tega, cenderung ceroboh, suka membuat garagara, emosional, dan seenaknya dalam melakukan kegiatan sehari-hari. ${ }^{14}$ Selain itu, apabila dilakukan toilet training pada anak dengan usia yang tidak tepat dapat menimbulkan beberapa masalah yang dialami anak yaitu seperti sembelit, menolak toileting, disfungsi berkemih, infeksi saluran kemih, dan enuresis. ${ }^{15}$

Kesiapan pada anak untuk melakukan toilet training, pengetahuan orang tua mengenai toilet training, dan pelaksanaan toileting yang baik dan benar pada anak, merupakan suatu domain penting yang perlu orangtua ketahui. Domain tersebut dapat meningkatkan kemampuan toilet training pada anak usia toddler. ${ }^{16}$ Perubahan perilaku anak bergantung kepada kualitas rangsangan yang berkomunikasi dengan lingkungan. Keberhasilan perubahan perilaku yang terjadi pada anak sangat ditentukan oleh kualitas dari sumber stimulus. Untuk membentuk jenis respon atau perilaku perlu diciptakan suatu kondisi yang disebut dengan operant conditioning, yaitu dengan menggunakan urutan-urutan komponen penguat. Komponenkomponen penguat tersebut adalah seperti pemberian hadiah atau penghargaan apabila melakukan suatu hal dengan benar. ${ }^{17}$

Berikutnya pola asuh yang terbukti mempengaruhi temper tantrum anak. Pola asuh sebagai bentuk interaksi orang tua terhadap fisik dan psikis anak. Keberhasilan keluarga dalam menanamkan nilai-nilai positif dan membentuk karakter yang baik pada anak dalam hidup bersosial dipengaruhi oleh pola asuh orang tua. Hasil penelitian membuktikan sikap pola asuh yang negatif terbukti secara statistik berpengaruh pada perilaku temper tantrum anak. Hal ini sejalan dengan penelitian Zakiyah tahun 2015 yang membuktikan adanya hubungan antara pola asuh orang tua dengan kejadian temper tantrum dengan $\mathrm{p}=$ 0,027. Dan juga didukung oleh penelitian Suyami tahun 2009 yang menyatakan ada hubungan pola asuh dengan perkembangan anak dalam aspek emosional. ${ }^{188}$ Jenis pola asuh atau didikan dari orang tua bisa mempengaruhi intensitas ledakan emosi anak. Anak yang selalu mendapatkan apa yang diinginkan, bisa temper tantrum kalau sekali waktu tidak mendapatkan. Anak yang terlalu dilindungi dan didominasi orang tua, maka bisa memicu untuk bereaksi menentang orang tua. Serta pada orang tua yang tidak disiplin dalam mendidik anak bisa membuat anak bingung dan memicu munculnya perilaku temper tantrum.

Suwaid tahun 2009 menambahkan pola asuh yang membiarkan anak menentukan sendiri batasan benar salah dalam berperilaku, orang tua tidak melakukan pengontrolan pada anak, sehingga anak tidak belajar menghormati dan bersosialisasi dengan orang lain, anak yang tidak menuruti aturan, egoisentris, sulit menerima larangan yang ada di lingkungan masyarakat, maka ketika anak tidak terpenuhi apa yang diinginkan maka anak akan berperilaku temper tantrum. ${ }^{19}$ Suryana tahun 2013 menjelaskan berdasarkan ahli perkembangan dan psikolog anak, temper tantrum sering terjadi karena anak mengalami frustasi dengan keadaannya, sedangkan dia tidak mampu mengungkapkan perasaannya dengan kata-kata atau ekspresi yang diinginkannya. ${ }^{3}$ Temper tantrum sering dialami oleh anak berusia 2-3 tahun, karena anak usia tersebut biasanya sudah mulai mengerti banyak hal dari yang didengar, dilihat, maupun dialaminya, tetapi kemampuan bahasa atau berbicaranya masih sangat terbatas.

Cara orang tua mengasuh anak berperan untuk menyebabkan tantrum. Anak terlalu dimanjakan dan selalu mendapatkan apa yang diinginkan, bisa tantrum ketika permintaannya ditolak. Anak yang terlalu dilindungi dan didominasi oleh orang tuanya, sekali waktu bisa bereaksi menentang dominasi orang tua dengan perilaku tantrum. ${ }^{3}$ Suryanatahun 2013 menjelaskan bahwa pengasuhan yang baik adalah dengan penuh kasih sayang, melakukan diskusi untuk setiap situasi agar membantu anak mengerti tentang alasan perilaku tertentu yang diharapkan, sehingga anak akan memiliki penyesuaian pribadi dan sosial yang baik, kemandirian, dan inisiatif yang sehat, positif sehingga bisa mengurangi perilaku temper tantrum. Pola asuh merupakan kunci pembentukan kepribadian dan emosi anak. Pola pengasuhan yang penuh kehangatan dan cinta kasih, tetapi juga memiliki batasan yang kuat dan jelas bisa mengurangi temper tantrum.

\section{SIMPULAN}

Penyapihan dini, toilet training dan pola asuh merupakan faktor orang tua yang mempengaruhi perilaku temper tantrum pada anak. Pada penelitian terbukti secara statistik signifikan bahwa penyapihan dini, toilet training dan pola asuh dalam mempengaruhi perilaku temper tantrum anak pra sekolah.

Faktor orang tua terbukti mempengaruhi perkembangan anak khususnya pada perkembangan personal sosial. Sehingga diharapkan orang tua mampu melakukan stimulasi yang baik pada anak. Pemberian ASI secara optimal sebagai salah satu bentuk stimulasi psikis yang bisa 
membangun hubungan batin antara ibu dan anak. Dengan kedekatan tersebut bisa berpengaruh pada emosi anak yang berdampak pada perkembangan aspek sosial, sehingga mengurangi kejadian perilaku temper tantrum.

Kesiapan pada anak untuk melakukan toilet training, pengetahuan orang tua mengenai toilet training, dan pelaksanaan toileting yang baik dan benar pada anak sebagai indikator pencapaian keberhasilan toilet training. Hal ini berdampak pada perilaku positif yang akan terbentuk pada anak, sehingga tidak terbentuk perilaku temper tantrum.

Pola asuh orang tua memberikan pengaruh pada perkembangan anak, karena orang tua merupakan lingkungan sosial pertama anak. Orang tua diharapkan menerapkan lingkungan sosial yang memfasilitasi dan memberikan peluang perkembangan anak secara optimal sesuai usianya. Orang tua diharapkan melakukan pengasuhan dengan penuh kasih sayang, melakukan diskusi untuk setiap situasi agar membantu anak mengerti tentang alasan perilaku tertentu yang diharapkan, sehingga anak akan memiliki penyesuaian pribadi dan sosial yang baik, kemandirian, dan inisiatif yang sehat, positif sehingga bisa mengurangi perilaku temper tantrum. Pola asuh merupakan kunci pembentukan kepribadian dan emosi anak. Pola pengasuhan yang penuh kehangatan dan cinta kasih, tetapi juga memiliki batasan yang kuat dan jelas bisa mengurangi temper tantrum.

\section{KEPUSTAKAAN}

1. Potter PA, Perry AG. Fundamental of Nursing, Buku 1 Edisi 7. Penerjemah, Nggie, FA Albar Mar Ed Hartanti Yayuk Salemba Med Jakarta. 2010;

2. Lestari, P. Hubungan Antara Tingkat Pengetahuan Ibu Tentang Toilet Training Dengan Praktik Ibu Dalam Penggunaan Diapers Pada Anak Usia Toddler (1-3 Tahun) Di Kelurahan Putat Purwodadi. Karya Ilm S 1 Ilmu Keperawatan. 2013;

3. Suryana, D. Pendidikan Anak Usia Dini. Padang: UNP Press; 2013.

4. Tandry, N. Bad Behaviour Tantrums And Tempers. Elex Media Komputindo; 2013.

5. Pusparini W, Arifah S. Hubungan Pengetahuan Ibu Tentang Toilet Training Dengan Perilaku Ibu Dalam Melatih Toilet Training. 1999;105-11.

6. Yus, A. Model pendidikan anak usia dini. Kencana;
2011.

7. Qurniyawati, E. The Giving Conformity on Stimulation for The Development of Children. Heal Notions. 2017;1(2):105-9.

8. Achmad IF, Latifah L, Husadayanti DN. Hubungan Tipe Pola Asuh Orang Tua dengan Emotional Quotient (EQ) pada Anak Usia Prasekolah (3-5 Tahun) di TK Islam Al-Fattaah Sumampir Purwokerto Utara. J Keperawatan Soedirman. 2010;5(1):47-57

9. Nugroho. Konsep Penyapihan. Yogyakarta: Pustaka Pelajar; 2011.

10. Stuebe, A. The risks of not breastfeeding for mothers and infants. Rev Obstet Gynecol. 2009;2(4):222.

11. Nugroho. Petunjuk Praktis Denver Development Screening Test. Jakarta: EGC; 2012.

12. Marmi. ASI Saja Mama Berilah Aku ASI karena Aku Bukan Anak Sapi. Yogyakarta: Pustaka Pelajar; 2012.

13. Hockenberry MJ, Wilson D. Wong's Essentials of Pediatric Nursing: Wong's Essentials of Pediatric Nursing. Elsevier Health Sciences; 2013.

14. Hidayat, A. Pengantar Ilmu Keperawatan Anak Jilid I. Jakarta Salemba Med Juherman, YN (2008) Pengetahuan, Sikap dan Peran Ayah terhadap Pemberian ASI Eksklus (Skripsi, Fak Pertanian, Inst Pertan Bogor, Bogor). 2005;

15. Hooman N, Safaii A, Valavi E, Amini-Alavijeh Z. Toilet training in Iranian children: a cross-sectional study. Iran J Pediatr. 2013;23(2):154.

16. Kusumaningrum A, Natosba J, Julia EL. Pengaruh Pendidikan Kesehatan Terhadap Perilaku Orang Tua Dalam Toilet Training Toddler. J Ilmu Kesehat Masy. 2011;2(02):97-102.

17. Maulana HDJ, Sos S, Kes M. Promosi kesehatan. In EGC; 2009.

18. Zakiyah N, Kurniawati T. Hubungan Pola Asuh Orang Tua dengan Kejadian Temper Tantrum pada Anak Usia Toddler di Dukuh Pelem Kelurahan Baturetno Banguntapan Bantul. STIKES'Aisyiyah Yogyakarta; 2015.

19. Suwaid, M. Mendidik anak bersama nabi; panduan lengkap pendidikan anak disertai kehidupan para salaf. Solo: Pustaka Arafah; 2009. 